\title{
ANALISIS KINERJA KEUANGAN MANCHESTER UNITED PLC SEBELUM DAN DI MASA PANDEMI COVID-19
}

\author{
Suparna Wijaya ${ }^{1}$, Tubagus Fathul Rizki Khoironi ${ }^{1}$ \\ ${ }^{1}$ Politeknik Keuangan Negara STAN, Tangerang Selatan,sprnwijaya@pknstan.ac.id \\ ${ }^{2}$ Politeknik Keuangan Negara STAN, Tangerang Selatan, 1302180141 fathul@pknstan.ac.id

\begin{tabular}{ll|lll} 
Article history & \multicolumn{1}{l}{} \\
\hline Dikirim tanggal & $: 17 / 08 / 2021$ & Diterima tanggal & $:$ & $31 / 08 / 2021$ \\
Revisi pertama tanggal & $: 25 / 08 / 2021$ & Tersedia online tanggal & $:$ & $15 / 09 / 2021$
\end{tabular}

\begin{abstract}
ABSTRAK
Penelitian ini bertujuan untuk membandingkan faktor-faktor yang mempengaruhi kinerja keuangan antara Manchester United Plc dan rata-rata industri sejenis dengan melihat tren rasio keuangan pada masa sebelum dan saat pandemi Covid-19. Objek yang diteliti yaitu klub sepak bola Manchester United sedangkan untuk rata-rata industri menggunakan enam klub sepak bola terbesar di Liga Primer Inggris yaitu Arsenal, Chelsea, Liverpool, Manchester City, Manchester United, dan Tottenham Hotspur. Penelitian ini menggunakan metode studi kepustakaan dengan cara mengumpulkan data serta informasi yang relevan sesuai topik yang dibahas melalui berbagai literatur. Selain metode studi kepustakaan, penelitian ini juga menggunakan indikator rasio keuangan yang diterapkan pada industri sepak bola untuk mengukur kinerja keuangan suatu klub sepak bola. Data yang digunakan adalah data sekunder berupa laporan keuangan perusahaan mulai tahun 2018 sampai dengan 2020 yang berasal dari situs resmi perusahaan. Hasil penelitian ini menunjukkan bahwa kinerja keuangan Manchester United cenderung mengalami penurunan, terutama dalam profitabilitas akibat penundaan kompetisi di masa pandemi Covid-19. Sebaliknya, kinerja keuangan Manchester United dinyatakan baik dalam hal pengelolaan beban gaji karyawan yang efisien dan pendapatan kontrak sponsor. Karena itu, investor perlu meninjau kondisi klub sepak bola berdasarkan rasio keuangan sebelum membuat keputusan investasi terhadap klub sepak bola.
\end{abstract}

Kata kunci: amortisasi pemain, biaya transfer, klub sepak bola, pendapatan pertandingan, rasio keuangan

\section{ABSTRACT}

English Premier League, such as Arsenal, Chelsea, Liverpool, Manchester City, Manchester United, and Tottenham Hotspur. This study used a literature study method by collecting relevant data and information according to the topics discussed through various literature. In addition, this study also uses financial ratio indicators applied to the football industry to measure the financial performance of a football club. The data used were secondary in the form of company financial statements from 2018 to 2020 from the company's official website. This study concludes that Manchester United's financial performance tends to decrease, especially in profitability, due to the postponement of the competition during the Covid-19 pandemic. On the other hand, Manchester United's financial performance started to be good in the efficiently managed employee payroll expenses and sponsorship contract revenues. Therefore, investors need to review the condition of football clubs based on financial ratios before making investment decisions on football clubs.

Keywords: player amortization, transfer fee, football club, matchday revenue, financial ratio

\section{PENDAHULUAN}

Di era modern ini, industri telah mengalami perkembangan pesat dari masa ke masa. Pada awalnya, masyarakat hanya mengenal beberapa sektor industri seperti perbankan, manufaktur, jasa, infrastruktur, bahkan agrikultur. Namun saat ini, tidak hanya sektor tersebut yang berkembang di dunia industri, tetapi banyak bermunculan juga industri-industri baru termasuk industri sepak bola. Sebagai salah satu olahraga yang 
paling digemari di dunia, daya tarik sepak bola seakan terus menyebar ke seluruh aspek kehidupan, termasuk aspek ekonomi dan bisnis. Kepopulerannya tersebut tidak lagi hanya sebagai cabang olahraga, tetapi sudah menjadi sebuah bisnis yang menguntungkan bagi pihak tertentu. Bahkan industri sepak bola telah menarik perhatian sejumlah pebisnis dunia untuk mengakuisisi sebuah klub sepak bola.

Aktivitas bisnis klub sepak bola sebenarnya sama dengan industri pada umumnya, namun ada sedikit keunikan pada aktivitas utama yang dijalankan sehingga hal tersebut berdampak pada laporan keuangannya. Keunikan tersebut melibatkan tiga aktivitas utama klub sepak bola profesional dengan menggunakan sebelas rasio keuangan (Amir \& Livne, 2005). Aktivitas pertama, klub sepak bola profesional biasanya memperoleh pendapatan dari tiga sumber, yaitu penjualan tiket pertandingan, pendapatan dari hak siar, dan pendapatan komersial (penjualan jersey, merchandise, sponsor, dan lainnya). Aktivitas kedua berasal dari transfer pemain sepak bola dan aktivitas ketiga dari pengembangan pemain usia muda. Dilihat dari sisi aset, klub sepak bola profesional memiliki aset tidak berwujud hampir separuh dari total aset yang ada di neraca. Aset tidak berwujud tersebut berupa kontrak pemain sepak bola yang harus diamortisasi setiap tahunnya.

Melihat banyaknya sumber pendapatan yang diperoleh, rasanya tidak mungkin bagi sebuah klub sepak bola profesional mengalami krisis keuangan ataupun memiliki banyak utang. Tetapi kenyataannya, banyak klub sepak bola profesional mengalami krisis keuangan. Ditambah lagi, kondisi pandemi Covid-19 yang terjadi saat ini membuat klub kehilangan sebagian besar pendapatannya dari penjualan tiket pertandingan karena adanya larangan suporter untuk datang ke stadion untuk menjaga penyebaran virus. Karena itu, perlu dilakukan analisis terhadap kinerja keuangan dari sebuah klub sepak bola sebelum dan di masa pandemi Covid-19 ini untuk mengetahui bagaimana sebuah klub mengelola keuangannya di masa pandemi ini.

Sejumlah penelitian mengenai akuntansi sebuah klub sepak bola profesional sudah pernah dilakukan baik di dalam negeri maupun luar negeri. Dari luar negeri, Ecer dan Boyukaslan (2014) menyatakan bahwa kontrak pemain sepak bola harus dikapitalisasi sebagai aset tidak berwujud dan diungkapkan dengan jelas mengenai informasi tambahan seperti akumulasi amortisasi, durasi kontrak rata-rata, nilai akuisisi, nilai tercatat, undertaken write downs, dan struktur organisasi. Dari dalam negeri, Lisvery dan Ginting (2004) meneliti perlakuan akuntansi mengenai sulitnya pengakuan, penilaian, pengukuran, dan pelaporan aset tidak berwujud dalam neraca. Hal ini selaras dengan penelitian Rahman (2017) yang meneliti pengakuan dan pencatatan aset tidak berwujud termasuk valuasi pemain pada klub di Liga Premier Inggris.

Beberapa penelitian yang ada lebih difokuskan membahas tentang human capital dan pelaporan keuangan sebuah klub. Laporan keuangan adalah laporan yang menunjukkan kondisi keuangan perusahaan saat ini atau periode kedepannya (Kasmir, 2013). Sedikit literatur yang meneliti kinerja keuangan dari klub sepak bola. Padahal laporan keuangan suatu klub sepak bola tidak sama dengan laporan keuangan perusahaan pada umumnya. Perbedaan itu dapat dilihat dari komponen-komponen keuangan karena aktivitas bisnisnya sehingga menarik untuk diteliti lebih dalam. Ditambah lagi fenomena pandemi Covid-19 yang terjadi saat ini memberikan suatu dampak yang tidak wajar pada aktivitas bisnis klub sepak bola.

Objek penelitian ini menggunakan studi kasus dari klub sepak bola Manchester United Plc. Pemilihan Manchester United Plc sebagai objek penelitian karena klub ini adalah klub sepak bola pertama yang berhasil melantai di bursa saham Amerika Serikat pada 10 Agustus 2012 dengan kode saham MANU berdasarkan data yang tercantum dalam website New York Stock Exchange. Selain itu, menurut laporan yang dirilis oleh 
KPMG dalam Football Benchmark, harga saham Manchester United Plc yang diatas US\$16 serta nilai pasar klub yang mencapai US\$3,25 miliar per Desember 2020 menunjukkan bahwa klub ini memiliki kinerja keuangan yang baik sehingga dapat dijadikan market leader dalam industri sepak bola.

Berdasarkan uraian latar belakang di atas, dapat diketahui bahwa industri sepak bola yang terus berkembang pesat menjadikan sepak bola bukan hanya sebagai olahraga atau permainan, melainkan menjadi sebuah bisnis yang menguntungkan. Karena itu, sebagai entitas bisnis, klub sepak bola perlu menyajikan laporan keuangan yang sesuai untuk melihat kinerja keuangannya. Tujuan penulisan ini adalah untuk mengetahui keunggulan kompetitif Manchester United Plc dibandingkan dengan perusahaan lain dalam satu sub industri sejenis; untuk mengetahui komponen keuangan utama dalam laporan keuangan Manchester United Plc; untuk mengetahui perlakuan akuntansi terhadap pemain sepakbola pada Manchester United Plc; dan untuk menganalisis kinerja keuangan Manchester United Plc dan rata-rata industri sejenis dengan melihat tren rasio keuangan sebelum dan di masa pandemi Covid-19 pada periode tahun 2018-2020.

\section{Karakteristik Kualitatif}

\section{KAJIAN PUSTAKA}

Subramanyam (2014) mengemukakan bahwa karakteristik kualitatif dari informasi dalam laporan keuangan akan membedakan mana informasi yang baik dengan informasi yang kurang baik. Hal ini karena adanya perbedaan metode akuntansi yang dipakai dan jenis informasi apa saja yang perlu diungkapkan agar bermanfaat untuk mengambil keputusan. Beberapa karakteristik kualitatif dari laporan keuangan yang harus dipenuhi adalah relevan, dapat dipahami, dapat dibandingkan, dan andal.

\section{Teori Kinerja Keuangan}

Kinerja keuangan diperlukan untuk menggambarkan sejauh mana perusahaan menjalankan bisnis operasionalnya serta seberapa efektif penggunaan aset perusahaan dalam menjalankan bisnisnya. Rudianto (2018) berpendapat bahwa kinerja keuangan merupakan hasil dari keterampilan perusahaan dalam mengelola asetnya secara efektif selama periode tertentu. Kinerja keuangan digunakan sebagai indikator keberhasilan perusahaan dalam menjalankan aktivitas keuangannya secara efisien dan efektif.

Penilaian kinerja keuangan mampu memberikan informasi mengenai perkiraan perusahaan dalam menghasilkan arus kas di masa depan dengan sumber daya yang tersedia serta bermanfaat bagi manajemen untuk mengambil keputusan bisnis tentang efektivitas sumber daya. Salah satu cara menilai kinerja dapat dilakukan dengan mengukur tingkat rasio keuangan yang ada. Munawir (2004) berpendapat bahwa ada beberapa tujuan dalam mengukur kinerja keuangan diantaranya mengukur tingkat likuiditas, yaitu ukuran yang menunjukkan kemampuan suatu perusahaan untuk memenuhi kewajiban keuangannya yang harus segera diselesaikan pada saat ditagih; mengukur tingkat solvabilitas, yaitu ukuran yang menunjukkan kemampuan perusahaan dalam memenuhi kewajiban keuangannya baik dalam jangka pendek maupun jangka panjang saat perusahaan dilikuidasi; mengukur tingkat profitabilitas, yaitu ukuran yang menunjukkan kemampuan perusahaan dalam menghasilkan keuntungan atau laba selama periode tertentu dengan modal secara efisien. Tingkat profitabilitas biasanya menjadi acuan terhadap keberlangsungan bisnis; dan mengukur tingkat aktivitas, yaitu ukuran yang menunjukkan efisiensi perusahaan dalam memanfaatkan aktiva guna menghasilkan kas dan pendapatan. Rasio ini dapat mengukur bagaimana kinerja perusahaan bersaing dengan industri sejenis berdasarkan tren dari waktu ke waktu. 


\section{Analisis Laporan Keuangan}

Analisis laporan keuangan merupakan evaluasi terhadap laporan keuangan untuk menilai kinerja perusahaan dan menciptakan produk berupa estimasi. Estimasi tersebut digunakan untuk mngambil keputusan bagi pihak berkepentingan dan mengurangi risiko ketidakpastian dalam analisis laporan keuangan perusahaan (Subramanyam, 2014). Sedangkan menurut Wahyudiono (2014), analisis laporan keuangan dapat dilakukan dengan cara membandingkan, mengevaluasi, serta menganalisis kecenderungan dari aspek-aspek keuangan perusahaan. Disamping itu, tujuan analisis laporan keuangan adalah membantu manajer melakukan tiga tugas penting lain diantaranya penilaian kinerja saat ini, pengendalian operasi, serta perencanaan kinerja masa yang akan datang.

Dalam melakukan analisis laporan keuangan, umumnya terdapat lima kriteria yang digunakan sebagai acuan dalam fundamental: Latar belakang perusahaan, likuiditas jangka pendek, efisiensi usaha, struktur modal dan solvensi jangka panjang, dan profitabilitas. Sehubungan dengan itu, Fraser dan Ormiston (2008) menyatakan ada beberapa langkah dalam melakukan analisis laporan keuangan, yaitu menentukan tujuan analisis, mempelajari bidang industri yang perusahaan jalani, mengembangkan pengetahuan mengenai kualitas manajemen, mengevaluasi laporan keuangan, dan mengikhtisarkan temuan serta mengambil kesimpulan.

\section{Analisis Rasio Keuangan}

Sujarweni (2019) berpendapat bahwa analisis rasio keuangan adalah suatu kegiatan untuk menggambarkan hubungan akun pada laporan berdasarkan perbandingan data suatu akun dengan akun lainnya. Perbandingan tersebut akan menghasilkan laporan keuangan meliputi neraca, laporan arus kas, dan laporan laba rugi. Sedangkan menurut Subramanyam (2014), analisis rasio keuangan menyajikan hubungan antara data-data yang dimuat dari laporan keuangan berbentuk persentase atau proporsi yang sederhana.

Analisis rasio keuangan bertujuan untuk menilai kinerja perusahaan karena hasilnya akan menggambarkan bagaimana kinerja keuangan dari perusahaan tertentu pada periode yang bersangkutan. Selain itu, analisis rasio keuangan dapat menilai keberhasilan perusahan dalam mengambil keputusan. Berdasarkan tujuannya, Robinson et al. (2009) menyatakan bahwa rasio keuangan dibagi menjadi empat jenis, yaitu likuiditas, profitabilitas, solvabilitas, dan aktivitas.

\section{Pelaporan Keuangan Klub Sepakbola}

Seperti hal nya sebuah perusahaan, klub sepak bola diharuskan untuk membuat pelaporan keuangan. Ada banyak peraturan mengenai klub sepak bola yang dirilis oleh FIFA sebagai federasi sepakbola tertinggi di dunia, salah satunya dalam FIFA Regulations Club Licensing pada Article 10 tentang financial criteria. Dalam aturannya, Federation Internationale de Football Association menyebutkan bahwa setiap negara dapat memiliki penyajian laporan keuangan yang berbeda tergantung kondisi ekonomi, sosial, dan implementasi dari financial kriteria itu sendiri sehingga hal tersebut akan memberikan tantangan baik bagi asosiasi maupun klub sepak bola di setiap negara. Bagi sebuah klub, financial criteria ini bertujuan untuk memperbaiki standar dan kualitas manajemen keaungan sehingga dapat meningkatkan kredibilitas bisnisnya sendiri.

Untuk memenuhi kriteria tersebut, klub sepak bola perlu menerapkan prinsip akuntansi yang berlaku sesuai dengan industri sepak bola. Sebuah penelitian mengenai Accounting for Football Club dalam situs studymode.com menyatakan bahwa akuntan memerlukan pemahaman yang mendalam mengenai industri sepak bola untuk menentukan prinsip akuntansi yang paling tepat diterapkan dalam klub sepak bola 
sehingga kinerja keuangannya dapat disajikan dengan baik. Hal ini tidak terlepas dari keunikan industri sepak bola mengenai fluktuasi dari laba dan pendapatannya sehingga sering terjadi ketidakpastian. Ditambah lagi, hasil yang diperoleh dari kompetisi reguler baik pertandingan liga, piala domestik, maupun kompetisi lain yang tidak dapat diprediksi sehingga memengaruhi jumlah pendapatan sebuah klub.

Menurut Club Licensing Regulation (2007), aturan yang dirilis oleh FIFA, menyebutkan jenis laporan keuangan tahunan diantaranya adalah Balance Sheets, Consolidated Profit \& Loss Account, dan Notes to the Accounts. Notes to the Accounts harus mengungkapkan minimal mengenai Accounting Policies, Controlling Party, Ultimate Owner, Related-party Transactions dan Other Disclosure.

\section{Akuntansi untuk Pemain Sepakbola}

Keunikan lain dalam industri sepak bola adalah adanya aturan akuntansi mengenai pemain sepak bola itu sendiri. Hidayat (2010) mengatakan bahwa pemain sepak bola adalah aset yang paling penting bagi sebuah klub yang muncul di laporan keuangan bagian neraca. Namun, anggapan aset yang penting tersebut bukan berarti tidak ada permasalahan mengenai pengakuan aset pemain. Beberapa aset sulit untuk diklasifikasikan karena memiliki sifat-sifat yang mewakili jenis aset termasuk atlet sepak bola. Atlet sepak bola bisa saja diklasifikasikan sebagai persediaan karena dapat diperjualbelikan antarklub demi mendapatkan keuntungan.

Ada banyak perdebatan mengenai apakah modal intelektual yang memiliki keterampilan seperti pemain sepak bola dapat diklasifikasikan sebagai aset perusahaan. Selanjutnya, Pranata dan Supatmi (2014) berpendapat bahwa salah satu value tambah bagi sebuah klub dapat dilihat dari aset pemain sepak bolanya. Hal ini dapat dikonfirmasi melalui nilai kontrak pemain. Hampir setengah dari aset perusahaan berisi nilai kontrak pemain sehingga aset di neraca perusahaan tidak akan mencerminkan value yang sebenarnya apabila nilai kontrak tersebut tidak diakui sebagai aset.

Berdasarkan kriteria aset yang ada, Hidayat (2010) berpendapat bahwa pemain sepak bola diakui sebagai aset perusahaan. Hal tersebut dikarenakan pemain sepak bola dapat dengan mudah diidentifikasi baik saat terjadi penjualan, penyewaan, pengendalian, pertukaran, maupun pemberian manfaat di masa depan. Manfaat masa depan yang dimaksud berupa jasa atau kontribusinya dalam pertandingan selama dikontrak oleh sebuah klub. Untuk menggolongkannya secara rinci, pemain sepak bola dapat dikategorikan sebagai aset tidak berwujud berdasarkan dua kriteria menurut IAS 38 yaitu dapat memberikan manfaat ekonomis di masa depan dan biaya perolehan dapat diukur secara andal. Seluruh biaya untuk kontrak pemain sepak bola harus dikapitalisasi ke nilai akuisisinya agar dapat mencerminkan posisi keuangan yang sebenarnya.

Selanjutnya, karena termasuk aset tidak berwujud, aset pemain sepak bola juga perlu dilakukan penyusutan, terhitung ketika aset sudah siap digunakan (Amir \& Livne, 2005). Jumlah aset pemain sepak bola yang disusutkan dengan masa manfaat terbatas harus dialokasikan secara sistematis selama masa manfaat. Mengenai metode amortisasi, International Accounting Standards (2004) membuat aturan bahwa metode harus dapat memperlihatkan pola manfaat ekonomi masa depan aset. Metode garis lurus digunakan apabila pola manfaat yang dimaksud sebelumnya tidak dapat ditentukan dengan andal.

Sesuai IAS 38, ketika sebuah aset tidak berwujud dilepas atau tidak lagi ada manfaat masa depan yang diharapkan dari pemakaiannya, maka aset tidak boleh diakui dan harus dihapuskan dari neraca, begitu pun dengan pemain sepak bola. Seorang pesepakbola yang masa kontraknya sudah habis atau dilepaskan untuk dijual ke klub lain, maka akun yang bersangkutan harus dihilangkan dari neraca. Mengenai keuntungan dan 
kerugian yang muncul dari penghentian serta pelepasan tersebut, perusahaan akan menghitung selisih antara jumlah penerimaan bersih dari pelepasan aset pemain dan nilai tercatat aset tersebut serta akan diakui dalam laporan laba rugi.

\section{METODE PENELITIAN}

Penelitian ini menggunakan metode studi kepustakaan dengan cara mengumpulkan data serta informasi yang relevan sesuai topik yang dibahas melalui berbagai literatur. Selain metode studi kepustakaan, penelitian ini juga menggunakan indikator rasio keuangan yang diterapkan pada industri sepak bola untuk mengukur kinerja keuangan suatu klub sepak bola melalui analisis data. Analisis ini dilakukan memulai berbagai tahapan, mulai dari mengumpulkan laporan keuangan Manchester United Plc, menganalisis komponen laporan keuangan klub sepak bola tersebut, melakukan perhitungan rasio keuangan dan analisis kinerja keuangannya, kemudian melakukan perbandingan dengan rasio industri sejenis untuk dapat menarik suatu kesimpulan mengenai kinerja keuangan. Data yang digunakan adalah data sekunder berupa laporan keuangan perusahaan mulai tahun 2018 sampai dengan 2020 yang berasal dari New York Stock Exchange. Perusahaan menerbitkan laporan keuangannya untuk periode yang berakhir pada 30 Juni.

\section{HASIL DAN PEMBAHASAN}

\section{Analisis Pelaporan Keuangan Manchester United Plc.}

Pada karya tulis ini, analisis dilakukan terhadap Manchester United Plc sebagai sebuah perusahaan dalam industri sepak bola. Manchester United Plc memiliki beberapa anak perusahaan yang laporan keuangannya akan dikonsolidasi di akhir tahun pelaporan. Kebijakan akuntansi dalam menyusun laporan keuangan konsolidasi tersebut sesuai dengan standar IFRS yang dikeluarkan oleh IASB. Manchester United Plc menjelaskan bahwa kerangka dasar pelaporan keuangan klub yang diterapkan bukanlah prinsip akuntansi yang berlaku umum di Amerika Serikat walaupun saham perusahaan tercatat di New York Stock Exchange. Namun, sebagai perusahaan go public tentu dituntut lebih dalam hal transparansi laporan sebagai implementasi dari penerapan Good Governance.

Tidak seperti perusahaan pada umumnya yang memiliki akhir periode akuntansi pada 31 Desember, laporan keuangan konsolidasi Manchester United disajikan untuk tahun yang berakhir pada 30 Juni. Hal ini tidak terlepas dari proses bisnis dari industri sepak bola. Dalam praktiknya, waktu pelaksanaan liga-liga Eropa diatur oleh UEFA (Union of European Football Associations) sebagai induk organisasi sepak bola di Eropa. Sebagian besar liga di Eropa memulai kompetisinya pada bulan Agustus dan berakhir bulan Mei tahun berikutnya sehingga pemilihan 30 Juni sebagai akhir periode pelaporan merupakan pilihan yang tepat. Semua informasi keuangan yang termasuk dalam Laporan Tahunan ini dinyatakan dalam poundsterling (£) dan semua nilai dibulatkan ke ribuan terdekat, kecuali dinyatakan lain.

Berdasarkan komponen keuangan yang dicantumkan oleh Manchester United, tampak ada sedikit perbedaan apabila dibandingkan dengan IAS 1 sebagai standar penyajian laporan keuangan. Pertama, untuk Statement of Profit or Loss (Laporan Laba Rugi) disajikan terpisah oleh Manchester United, sedangkan laporan laba rugi dalam IAS 1 sudah tercantum dalam Statement of Comprehensive Income. Perbedaan kedua ada pada penggunaan judul "Consolidated Balance Sheet" di laporan keuangan Manchester United, sementara menurut standar IAS 1 menggunakan judul Statement of Financial 
Position untuk laporan neraca. Meski begitu, IAS 1 memperbolehkan penggunaan judul lain dan juga pemisahan laporan laba rugi dengan catatan-catatan tertentu.

Tabel 1.

Perbandingan Komponen Laporan Keuangan

\begin{tabular}{ll}
\hline \multicolumn{1}{c}{ IAS 1 } & \multicolumn{1}{c}{ Manchester United } \\
\hline $\begin{array}{l}\text { Statement of Financial Position } \\
\text { Statement of Comprehensive }\end{array}$ & $\begin{array}{l}\text { Consolidated Balance Sheet } \\
\text { Consolidated Statement of Profit or Loss dan } \\
\text { Income }\end{array}$ \\
Consolidated Statement of Comprehensive Income \\
Statement of Change in Equity & Consolidated Statement of Changes in Equity \\
\hline
\end{tabular}

Sumber: Diolah penulis (2021)

Analisis atas Laporan Laba Rugi Manchester United Plc.

Analisis atas Komponen Revenue

Dalam menghasilkan pendapatan, Manchester United meninjaunya melalui tiga sektor utama, yaitu komersial, hak siar, dan pendapatan dari tiket pertandingan (matchday). Untuk sektor pendapatan komersial dapat dihasilkan dari beberapa aliran dana dari pendapatan sponsor, lisensi retail, dan merchandising. Selanjutnya, pihak klub melaporkan total pendapatan dengan nama Revenue from contracts with customers dalam laporan laba ruginya. Total Revenue from contracts with customers menunjukkan imbalan yang diterima atau piutang dari aktivitas utama klub (komersial, hak siar, dan pertandingan) namun tidak termasuk biaya transfer dan pajak pertambahan nilai. Per periode terbaru 2020, pihak klub melaporkan revenue sebesar $£ 509.041 .000$.

Tabel 2.

Sumber Pendapatan Manchester United Plc untuk Periode 2019-2020

\begin{tabular}{lcccc}
\hline \multicolumn{1}{c}{ Sumber Revenue } & 2020 & 2019 & \multicolumn{2}{c}{ Kenaikan (Penurunan) } \\
\cline { 2 - 5 } & $£^{\prime} 000$ & $£^{\prime} 000$ & $£^{\prime} 000$ & $\%$ \\
\hline Commercial & & & & \\
$\quad$ Sponsorship & 182.709 & 173.010 & 9.699 & $5,61 \%$ \\
$\quad$ Retail, merchandising, \& licensing revenue & 96.335 & 102.083 & $(5.748)$ & $(5,63 \%)$ \\
$\quad$ Total Commercial (1) & $\mathbf{2 7 9 . 0 4 4}$ & $\mathbf{2 7 5 . 0 9 3}$ & $\mathbf{3 . 9 5 1}$ & $\mathbf{1 , 4 4 \%}$ \\
Broadcasting & & & & \\
$\quad$ Domestic competitions & 115.415 & 148.018 & $(32.603)$ & $(22,03 \%)$ \\
$\quad$ European competitions & 16.836 & 83.138 & $(66.302)$ & $(79,75 \%)$ \\
$\quad$ Other & 7.952 & 10.054 & $(2.102)$ & $(20,91 \%)$ \\
$\quad$ Total Broadcasting (2) & $\mathbf{1 4 0 . 2 0 3}$ & $\mathbf{2 4 1 . 2 1 0}$ & $\mathbf{( 1 0 1 . 0 0 7 )}$ & $\mathbf{( 4 1 , 8 8 \% )}$ \\
Matchday (3) & $\mathbf{8 9 . 7 9 4}$ & $\mathbf{1 1 0 . 8 1 9}$ & $\mathbf{( 2 1 . 0 2 5 )}$ & $\mathbf{( 1 8 , 9 7 \% )}$ \\
Total Revenue (1+2+3) & $\mathbf{5 0 9 . 0 4 1}$ & $\mathbf{6 2 7 . 1 2 2}$ & $\mathbf{( 1 1 8 . 0 8 1 )}$ & $\mathbf{( 1 8 , 8 3 \% )}$ \\
\hline
\end{tabular}

Sumber: Diolah dari laporan keuangan Manchester United Plc

Pendapatan kotor total Manchester United untuk tahun yang berakhir pada 30 Juni 2020 adalah $£ 509$ juta, mengalami penurunan sebesar $£ 118,1$ juta atau $18,83 \%$ dibandingkan periode 30 Juni 2019. Secara persentase, satu-satunya sumber pendapatan yang mengalami kenaikan adalah pendapatan komersial, meningkat sebesar $£ 3,9$ juta atau $1,44 \%$ dibandingkan periode sebelumnya. Hal ini tidak terlepas dari peningkatan pendapatan sponsor sebesar 5,61\% akibat peningkatan kesepakatan dengan Perusahaan General Motors (Chevrolet) dan Aon sebagai mitra pelatihan klub. 
Pendapatan penyiaran (broadcasting) berdasarkan kesepakatan hak siar dari beberapa sumber, seperti Sky Sports, BT Sport, dan Amazon Prime Video. Ditambah lagi pendapatan dari siaran MUTV. Meskipun broadcasting ini berasal dari banyak sumber pendapatan, pendapatan penyiaranlah yang mengalami penurunan signifikan, yaitu turun hampir $£ 101$ juta atau $41,88 \%$ di periode 2020. Hal ini disebabkan karena tidak berpartisipasinya Manchester United dalam Liga Champions Eropa, ditambah penundaan sepuluh pertandingan yang berkaitan dengan kompetisi 2019/2020 dan direncanakan kembali bertanding pada tahun 2021 akibat adanya pandemi Covid-19 sehingga mengganggu proses jadwal siaran secara keseluruhan. Sumber revenue lain yang turun cukup signifikan pada periode 2020 adalah dari tiket pertandingan (matchday). Pendapatan pertandingan per 20 Juni 2020 adalah $£ 89,8$ juta, turun sebesar $£ 21$ juta atau sekitar 18,97\%. Penurunan terjadi karena pertandingan di Old Trafford (kandang Manchester United) harus dimainkan secara tertutup akibat pandemi pandemi Covid-19 dan penonton tidak diperbolehkan memasuki stadion untuk menghindari penyebaran virus sehingga berpengaruh terhadap pendapatan sektor tiket pertandingan. Sektor komersial menjadi pendorong profitabilitas perusahaan di masa pandemi Covid-19 namun secara keseluruhan pendapatan kotor perusahaan cenderung mengalami penurunan yang cukup besar terutama sektor penyiaran dan pendapatan pertandingan.

Analisis atas Komponen Expenses

Kemampuan sebuah klub dalam memperoleh pendapatan tidak selalu sejalan dengan dalam memperoleh laba. Hal ini terjadi apabila perusahaan tidak dapat mengelola expenses dengan baik. Karena itu, sumber beban tersebut dapat menjadi salah satu hal yang berpengaruh pada laba perusahaan. Dalam laporan laba rugi, Manchester United mengklasifikasikan beban dalam tiga jenis, yaitu operating expenses, net finance costs, dan income tax expense. Pada periode 30 Juni 2020, total beban Manchester United senilai $£ 550,6$ juta, lebih kecil $£ 83,3$ juta dibandingkan periode sebelumnya. Penurunan tersebut dialami oleh sebagian besar akun dalam beban. Hal ini seiring dengan penurunan pendapatan akibat pandemi Covid-19 yang mengharuskan kompetisi ditunda sampai periode berikutnya sehingga beban yang dihasilkan lebih sedikit dari biasanya.

Tabel 3.

Sumber Beban Manchester United Plc untuk Periode 2019-2020

\begin{tabular}{lcccc}
\hline \multirow{2}{*}{ Sumber Expenses } & 2020 & 2019 & \multicolumn{2}{c}{ Kenaikan (Penurunan) } \\
\cline { 2 - 5 } & $£^{\prime} 000$ & $£^{\prime} 000$ & $£^{\prime} 000$ & $\%$ \\
\hline Operating Expenses & & & & \\
Employee benefit expenses & 284.029 & 332.356 & $(48.327)$ & $(14,54 \%)$ \\
Other operating expenses & 92.876 & 108.977 & $(16.101)$ & $(14,77 \%)$ \\
Depreciation and impairment & 18.543 & 12.850 & 5.693 & $44,30 \%$ \\
Amortization & 126.756 & 129.154 & $(2.398)$ & $(1,86 \%)$ \\
Exceptional items & - & 19.599 & $(19.599)$ & $(100,00 \%)$ \\
Total Operating Expenses (1) & $\mathbf{5 2 2 . 2 0 4}$ & $\mathbf{6 0 2 . 9 3 6}$ & $\mathbf{( 8 0 . 7 3 2 )}$ & $\mathbf{( 1 3 , 3 9 \% )}$ \\
Net Finance Costs (2) & $\mathbf{2 6 . 0 3 9}$ & $\mathbf{2 2 . 5 0 9}$ & $\mathbf{3 . 5 3 0}$ & $\mathbf{1 5 , 6 8 \%}$ \\
Income Tax Expense (3) & $\mathbf{2 . 4 1 5}$ & $\mathbf{8 . 5 9 5}$ & $\mathbf{( 6 . 1 8 0 )}$ & $\mathbf{( 7 1 , 9 0 \% )}$ \\
Total Expenses (1+2+3) & $\mathbf{5 5 0 . 6 5 8}$ & $\mathbf{6 3 4 . 0 4 0}$ & $\mathbf{( 8 3 . 3 8 2})$ & $\mathbf{( 1 3 , 1 5 \% )}$ \\
\hline
\end{tabular}

Sumber: Diolah dari laporan keuangan Manchester United Plc

Dari ketiga jenis beban tersebut, proporsi operating expenses menjadi yang paling banyak, sebesar lebih dari $90 \%$ dari total seluruh beban pada periode sebelum maupun di masa pandemi Covid-19. Operating expenses terdiri dari beberapa aspek, seperti beban 
tunjangan pekerja (employee benefit expense), biaya operasional lainnya, depresiasi dan penurunan nilai, amortisasi, dan pos luar biasa. Beban tunjangan pekerja memiliki proporsi hampir separuh dari total seluruh beban. Per periode 30 Juni 2020, beban tunjangan pekerja senilai $£ 284$ juta, turun $£ 48,3$ juta atau $14,5 \%$ dibandingkan periode 2019. Pengurangan ini sebagai dampak dari pelepasan pemain, kesepakatan pinjaman, dan pengurangan kontrak gaji karena tidak berpartisipasi di Liga Champions Eropa. Gaji pemain di Eropa sangatlah tinggi sehingga berpengaruh besar terhadap nominal beban.

Penurunan juga terjadi pada beban operasional lainnya, yaitu sebesar $14,77 \%$. Beban operasional lainnya periode 2020 menunjukkan nominal $£ 92,8$ juta atau lebih kecil $£ 16,1$ juta dibandingkan periode 2019 sebesar £108,9 juta. Hal ini terjadi karena berkurangnya aktivitas bisnis akibat pandemi Covid-19, termasuk penundaan pertandingan kandang Liga Premier Inggris, beberapa pertandingan yang dimainkan tanpa penonton, dan penutupan toko merchandise di Old Trafford menyebabkan pengurangan beban operasional. Sama seperti beban operasional lainnya, pengurangan nilai beban juga berlaku pada amortisasi dan pos luar biasa. Amortisasi terutama mengenai pendaftaran pemain mengalami penurunan sebesar $1,9 \%$ dibandingkan periode sebelumnya akibat renegosiasi kontrak dan beban pos luar biasa hanya terjadi pada periode 30 Juni 2019 karena adanya kompensasi kepada Jose Mourinho sebagai mantan pelatih tim putra Manchester United F.C dan staf pelatih karena pemecatan berkala.

Sementara itu, kenaikan terjadi pada beban depresiasi dan penurunan nilai. Per periode 30 Juni 2020, depresiasi dan penurunan nilai sebesar $£ 18,54$ juta, meningkat $£ 5,7$ juta atau 44,3\% dibandingkan periode 2019 . Hal tersebut terjadi karena penurunan nilai properti investasi setelah dampak Covid-19.

\section{Player's Registration Manchester United F.C.}

Seperti prinsip akuntansi pada umumnya, pemain sepak bola harus diungkapkan dalam laporan keuangan ketika telah diakui sebagai aset perusahaan. Dalam Catatan atas Laporan Keuangannya, Manchester United mengklasifikasikan pemain sepak bola sebagai Aset Tidak Berwujud bagian dari Registration. Hal ini berdasarkan pertimbangan bahwa yang dilihat dari seorang pemain sepak bola adalah kemampuan bermain yang dimiliki sehingga termasuk dalam aset tidak berwujud. Pemain sepak bola Manchester United terdiri dari tim pria, tim wanita serta tim muda yang masih berada di akademi. Namun tim pria sangat berpengaruh besar terhadap keuangan Manchester United.

Pengukuran nilai wajar pemain dinilai berdasarkan semua biaya terkait akuisisi pemain serta biaya lainnya sampai seorang pemain siap digunakan jasanya. Biaya yang dimaksud juga termasuk biaya transfer, retribusi Liga Primer Inggris, biaya agen, dan biaya lain yang dapat diatribusikan. Biaya perolehan atas Registration akan disesuaikan setiap akhir periode keuangan melalui amortisasi. Metode yang digunakan adalah garis lurus (straight line) dengan masa manfaat sesuai kontrak. Nilai yang tertulis dalam kontrak pemain adalah jumlah yang ditetapkan berdasarkan pertimbangan profesional dari Departemen Pengamatan (Scouting Department) melalui pertimbangan tertentu. Ketika ada kontrak yang diperpanjang, maka semua biaya yang dikeluarkan akan dikapitalisasi ke dalam biaya perolehan ditambah nilai tercatat yang belum diamortisasi. 
Tabel 4.

Saldo Buku Player's Registration

\begin{tabular}{lc}
\hline \multicolumn{1}{c}{ Player's Registration } & Total (£'000) \\
\hline At 30 June 2019 & \\
Cost & 772.328 \\
Accumulated amortization & $(433.566)$ \\
$\quad$ Net book amount & $\mathbf{3 3 8 . 7 6 2}$ \\
At 30 June 2020 & \\
Cost & 831.275 \\
Accumulated amortization & $(484.403)$ \\
Net book amount & $\mathbf{3 4 6 . 8 7 2}$ \\
\hline
\end{tabular}

Sumber: Diolah dari Laporan Keuangan Manchester United Plc

Tabel 4 menunjukkan saldo registrasi yang belum diamortisasi per periode 30 Juni 2020 adalah sebesar $£ 346,9$ juta. Sisa saldo diperkirakan akan diamortisasi selama empat tahun hingga 30 Juni 2025. Hal tersebut belum memperhitungkan penambahan pemain setelah akhir periode pelaporan yang akan berdampak pada peningkatan biaya amortisasi di periode mendatang dan juga tidak mempertimbangkan pelepasan pemain setelah akhir periode yang akan mengurangi biaya amortisasi di masa depan.

Keuntungan dan kerugian dari pelepasan Player's Registrations ditentukan berdasarkan perbandingan antara nilai wajar dari piutang setelah dikurangi biaya transaksi dengan jumlah tercatat dan diakui secara terpisah dalam laba pelepasan aset tak berwujud. Tabel 5 dibawah ini menunjukkan laba pelepasan aset tak berwujud (Registrations) untuk periode 2020 sebesar $£ 18,38$ juta, lebih sedikit dibandingkan laba pada periode 2019 yaitu sebesar $£ 25,79$ juta. Hal ini tidak terlepas dari kesuksesan Manchester United dalam bernegosiasi dan melepas beberapa pemain andalannya di 2019, seperti Blind (dipindahkan ke Ajax), Johnstone (dipinjamkan ke West Bromwich Albion), dan Fellaini (dipindahkan ke Shandong Luneng). Keuntungan pelepasan pemain pada periode 2020 berasal dari hasil penjualan Romero Lukaku ke Inter Milan.

Tabel 5.

Laba Pelepasan Aset Tidak Berwujud (Player's Registrations)

\begin{tabular}{|c|c|c|}
\hline Profit on disposal of intangible assets & $2020\left(£^{\prime} 000\right)$ & $2019\left(\mathfrak{f}^{\prime} 000\right)$ \\
\hline Profit on disposal of registrations & 15.664 & 24.720 \\
\hline Player loan income & 2.720 & 1.079 \\
\hline Total & 18.384 & 25.799 \\
\hline
\end{tabular}

Sumber: Laporan Keuangan Manchester United Plc

\section{Analisis Rasio Keuangan Manchester United Plc.}

Analisis ini untuk meneliti laporan keuangan Manchester United periode 20182020 dibandingkan dengan rata-rata industri sejenis untuk menggambarkan kinerja keuangan sebelum dan di masa pandemi Covid-19. Namun, hal ini memiliki keterbatasan data. Oleh karena itu, sampel yang digunakan untuk rata-rata industri pembanding hanyalah klub-klub besar sepak bola di Liga Primer Inggris atau lebih dikenal dengan sebutan The Big Six Premier League, yaitu enam klub yang belum pernah terdegradasi selama dua dekade terakhir sehingga laporan keuangan antar klub cukup stabil serta layak untuk diperbandingkan. Dari klub yang berkompetisi di Liga Inggris tersebut, klub yang memenuhi kriteria sebagai objek rata-rata industri diantaranya Arsenal, Chelsea, Liverpool, Manchester City, Manchester United, dan Tottenham Hotspur. 
Dalam menganalisis keuangan, penulis menggunakan enam dari sebelas rasio keuangan khusus sepak bola yang mengacu pada penelitian Amir dan Livne (2005), yaitu: (1) Current Sales Ratio, (2) Operating Profit Before Transfer Fees Ratio, (3) Current Wages Ratio, (4) Total Asset to Total Sales Ratio, (5) Net Investment in Player Contract, dan (6) Adjusted Leverage Ratio. Selain enam rasio dari peneliti terdahulu, penulis menambahkan rasio likuiditas berupa Current Ratio, rasio profitabilitas berupa Return on Asset untuk menghitung profit dari sebuah klub, rasio solvabilitas dalam Debt to Equity Ratio untuk mengukur kemampuan klub untuk membayar kewajibannya, serta rasio aktivitas berupa Assets Turnover.

Selanjutnya, setelah melakukan perhitungan atas sepuluh rasio tersebut maka penulis akan membandingkan rasio keuangan Manchester United Plc dengan rata-rata industri sejenis selama tahun 2018-2020. Berikut ini akan dibahas mengenai enam rasio keuangan sepak bola dan empat rasio keuangan lainnya yang diperoleh dari hasil pengolahan data keuangan Manchester United dan rata-rata industrinya.

Analisis rasio keuangan sepak bola menurut penelitian Amir dan Livne

Current Sales Ratio

Rasio ini digunakan untuk mengetahui kenaikan pendapatan selama periode tertentu. Semakin tinggi current sales maka pertumbuhan penjualan perusahaan semakin baik. Pada periode 2018-2020, current sales Manchester United masing-masing sebesar $101,46 \%$ kemudian mengalami peningkatan menjadi 106,34\% dan terakhir turun drastis menjadi 81,17\%. Sedangkan current sales rata-rata industri dari 2018 sampai 2020 sebesar 98,99\%, 108,37\%, serta mengalami penurunan menjadi 87,63\%. Baik Manchester United maupun rata-rata industrinya mencapai pertumbuhan penjualan maksimum pada 2019 dan sama-sama mengalami penurunan drastis pada 2020.

Tabel 6.

Perbandingan Current Sales Ratio antara Manchester United Plc dan Rata-Rata Industri Selama Periode 2018-2020

\begin{tabular}{ccccc}
\hline \multirow{2}{*}{ Objek } & \multicolumn{4}{c}{ Tahun } \\
\cline { 2 - 5 } & $\mathbf{2 0 1 8}$ & $\mathbf{2 0 1 9}$ & $\mathbf{2 0 2 0}$ & $\overline{\mathbf{x}}$ \\
\hline Manchester United & $101,46 \%$ & $106,34 \%$ & $81,17 \%$ & $96,32 \%$ \\
Rata-rata industri & $98,99 \%$ & $108,37 \%$ & $87,63 \%$ & $98,33 \%$ \\
\hline
\end{tabular}

Sumber: Diolah dari laporan keuangan klub Liga Inggris (2021)

Rata-rata current sales Manchester United berada di bawah rata-rata industri sejenis. Namun, current sales Manchester United mengalami fluktuasi yang cukup tinggi. Kenaikan sempat terjadi di tahun 2019 kemudian turun pada periode 2020. Penurunan current sales Manchester United pada periode 2020 terjadi karena penjualan tiket dan pendapatan hak siar klub turun secara drastis. Meskipun komponen terbesar berasal dari pendapatan komersial yaitu sebesar 43,87\% dan 54,82\% pada periode 2019 dan 2020, penurunan pendapatan hak siar dan tiket klub tetap memengaruhi penjualan. Peraturan terkait pelarangan penonton di stadion sebagai tindak lanjut adanya pandemi Covid-19 menjadi faktor yang sangat merugikan kondisi klub pada periode 2020. Dapat disimpulkan bahwa secara tren current sales Manchester United cenderung menurun dan berada di bawah rata-rata industri. Manchester United merasakan dampak akibat pandemi Covid-19 dengan penurunan yang cukup signifikan di tahun 2020 sebanyak 25,17\%. Hal tersebut cukup mengkhawatirkan untuk sebuah klub sepak bola karena sumber pendapatan utamanya menjadi terganggu. 
Operating Profit Before Transfer Fees Ratio

Rasio ini untuk mengetahui laba operasi dengan membandingkan laba sebelum biaya transfer, pajak, dan beban bunga dengan total pendapatan pada periode tertentu.

Tabel 7.

Perbandingan Operating Profit Before Transfer Fees Ratio antara

Manchester United Plc dan Rata-Rata Industri Selama Periode 2018-2020

\begin{tabular}{ccccc}
\hline \multirow{2}{*}{ Objek } & \multicolumn{4}{c}{ Tahun } \\
\cline { 2 - 5 } & $\mathbf{2 0 1 8}$ & $\mathbf{2 0 1 9}$ & $\mathbf{2 0 2 0}$ & $\overline{\mathbf{x}}$ \\
\hline Manchester United & $7,44 \%$ & $7,97 \%$ & $1,03 \%$ & $5,48 \%$ \\
Rata-rata industri & $0,94 \%$ & $-3,11 \%$ & $-18,83 \%$ & $-7,00 \%$ \\
\hline
\end{tabular}

Sumber: Diolah dari laporan keuangan klub Liga Inggris (2021)

OPROF Manchester United masing-masing sebesar 7,44\%, 7,97\%, dan sempat turun cukup jauh menjadi 1,03\% selama rentang 2018-2020. Di sisi lain, OPROF ratarata industri sejenis pada periode yang sama sebesar $0,94 \%,-3,11 \%$, dan $-18,83 \%$. Data tersebut menunjukkan rata-rata $O P R O F$ Manchester United berada di atas rata-rata industri sejenis, yaitu sebesar 5,48\%. Berbeda jauh dengan rata-rata OPROF industri sejenis yang mencapai $-7 \%$. Secara tren, sebenarnya baik OPROF Manchester United maupun industri sejenisnya sama-sama mengalami penurunan. Penurunan OPROF Manchester United terjadi karena aktivitas bisnis pada periode 2020 mengalami penurunan akibat pandemi Covid-19 sehingga beban operasi lebih besar daripada pendapatannya. Namun, Manchester United hanya mengalami sedikit penurunan, dibuktikan dengan nilai $O P R O F$ yang selalu positif dan tren grafik yang landai sehingga nilai $O P R O F$ cenderung stabil. Sementara itu, $O P R O F$ sebagian rata-rata industri mengalami kerugian dari operasional yang cukup signifikan karena beban operasi terutama gaji pemain lebih besar dari penjualannya. Hal tersebut ditandai dengan grafik yang curam pada periode 2020 .

Secara umum dapat dikatakan bahwa laba operasi Manchester United dibandingkan penjualannya selama tiga tahun terakhir cukup memuaskan karena masih dapat bertahan dan bernilai positif dibandingkan industri lain yang sebagian besar mengalami penurunan drastis pada laba operasinya. Di lain hal, $O P R O F$ rata-rata industri sejenis cukup buruk karena dalam periode 2018-2020 mengalami kerugian operasional yang besar sehingga beban operasi mengakibatkan kecilnya laba operasi.

\section{Current Wages Ratio}

Current wages ratio adalah rasio yang digunakan untuk mengukur seberapa besar penjualan pada periode tertentu dapat membiayai beban gaji perusahaan. Rasio ini dapat dicari dengan membandingkan beban gaji dengan pendapatan atau penjualan di periode berjalan. Semakin kecil current wages ratio yang dihasilkan maka kinerja keuangan semakin baik. Sementara itu, rata-rata current wages Manchester United sebesar 46,39\%, berada di bawah industri sepak bola sejenis yang memiliki rata-rata 50,02\%. Artinya, kinerja keuangan Manchester United cukup baik apabila ditinjau dari current wages ratio. 
Tabel 8.

Perbandingan Current Wages Ratio antara Manchester United Plc dan

Rata-Rata Industri Selama Periode 2018-2020

\begin{tabular}{ccccc}
\hline \multirow{2}{*}{ Objek } & \multicolumn{4}{c}{ Tahun } \\
\cline { 2 - 5 } & $\mathbf{2 0 1 8}$ & $\mathbf{2 0 1 9}$ & $\mathbf{2 0 2 0}$ & $\overline{\mathbf{x}}$ \\
\hline Manchester United & $43,35 \%$ & $46,79 \%$ & $49,03 \%$ & $46,39 \%$ \\
Rata-rata industri & $45,73 \%$ & $48,72 \%$ & $55,60 \%$ & $50,02 \%$ \\
\hline
\end{tabular}

Sumber: Diolah dari laporan keuangan klub Liga Inggris (2021)

Berdasarkan tabel di atas diketahui bahwa dalam periode 2018-2020, baik current wages Manchester United maupun industri sepak bola yang sejenis cenderung mengalami kenaikan. Pada periode 2019, current wages Manchester United mengalami kenaikan sebesar 3,44\% menjadi 46,79\%. Begitu memasuki periode 2020, current wages Manchester United kenaikannya masih cukup stabil dari 46,79\% menjadi 49,03\%. Kenaikan current wages rata-rata industri selama periode 2018-2020 disebabkan oleh beberapa faktor. Persaingan dari klub-klub besar Liga Primer Inggris membuat klub menghabiskan banyak biaya untuk transfer dan gaji pemain. Setiap kenaikan gaji dapat memengaruhi bisnis dan kondisi keuangan klub sepak bola. Sementara itu, kenaikan beban gaji pemain dan staff tim Manchester United akibat jumlah karyawan juga meningkat diiringi dengan pertumbuhan pendapatan komersial yang baik sehingga kenaikan current wages masih cukup stabil.

Secara keseluruhan, rasio current wages Manchester United lebih baik dibanding rata-rata industri. Hal ini dikarenakan selisih antara pendapatan dan gaji yang begitu besar sehingga biaya gaji dapat diimbangi dengan penjualan yang besar dari klub. Sebaliknya, current wages rata-rata industri tidak begitu baik karena biaya gaji dan penjualan memiliki selisih yang kecil sehingga kenaikan pembayaran gaji kurang sepadan dengan hasil penjualannya.

Total Assets to Total Sales Ratio

Rasio ini digunakan untuk membandingkan total aset dengan penjualan tahun sebelumnya. Manchester United memiliki rata-rata TATS sebesar 246,76\%, lebih tinggi dibandingkan rata-rata industri sejenis yang memiliki TATS 240,91\%. Manchester United cenderung mengalami penurunan walaupun tidak terlalu signifikan. Manchester United mengalami penurunan TATS dari 265,93\% menjadi 253,75\% pada periode 2019 dan kembali turun menjadi sebesar 220,61\% di tahun 2020. Hal ini sebagai dampak adanya pandemi Covid-19. Penerimaan kas pertandingan menjadi turun drastis akibat ketidakpastian mengenai larangan menonton langsung di stadion.

Tabel 9.

Perbandingan Total Asset to Total Sales Ratio antara Manchester United PLC dan Rata-Rata Industri Selama Periode 2018-2020

\begin{tabular}{ccccc}
\hline \multirow{2}{*}{ Objek } & \multicolumn{4}{c}{ Tahun } \\
\cline { 2 - 5 } & $\mathbf{2 0 1 8}$ & $\mathbf{2 0 1 9}$ & $\mathbf{2 0 2 0}$ & $\overline{\mathbf{x}}$ \\
\hline Manchester United & $265,93 \%$ & $253,75 \%$ & $220,61 \%$ & $246,76 \%$ \\
Rata-rata industri & $234,07 \%$ & $254,16 \%$ & $234,50 \%$ & $240,91 \%$ \\
\hline
\end{tabular}

Sumber: Diolah dari laporan keuangan klub Liga Inggris (2021) 
Rata-rata industri sempat mengalami kenaikan menjadi 254,16\% di tahun 2019 kemudian turun cukup drastis menjadi $234,50 \%$ pada periode 2020 . Hal ini selain karena pandemi Covid-19 juga dipengaruhi oleh sebagian besar The Big Six yang gagal bersaing di Liga Champions Eropa sehingga cukup besar memengaruhi arus kas sebuah klub. Secara keseluruhan TATS Manchester United lebih baik daripada rata-rata industri karena pengaruh keikutsertaan Manchester United dalam kompetisi Eropa sehingga sumber penerimaan kas menjadi bertambah karena pendapatan melalui pertandingan.

Net Investment in Player Contracts

Rasio ini digunakan untuk menghitung selisih antara pembelian (transfer in) dan penjualan (transfer out) pemain terhadap pendapatan perusahaan. Semakin kecil rasio maka kemampuan perusahaan dalam menginvestasikan kontrak pemain semakin baik.

Tabel 1.

Perbandingan Net Investment in Player Contracts antara Manchester United PLC dan Rata-Rata Industri Selama Periode 2018-2020

\begin{tabular}{ccccc}
\hline \multirow{2}{*}{ Objek } & \multicolumn{4}{c}{ Tahun } \\
\cline { 2 - 5 } & 2018 & 2019 & 2020 & $\overline{\mathrm{x}}$ \\
\hline Manchester United & $36,62 \%$ & $15,11 \%$ & $25,71 \%$ & $25,82 \%$ \\
Rata-rata industri & $23,40 \%$ & $18,62 \%$ & $11,82 \%$ & $17,95 \%$ \\
\hline
\end{tabular}

Sumber: Diolah dari laporan keuangan klub Liga Inggris (2021)

Berdasarkan Tabel 12 terlihat bahwa rata-rata NINV Manchester United berada di atas rata-rata industri. Meskipun begitu, secara tren rata-rata industri sejenis cenderung menurun sedangkan rasio NINV Manchester United mengalami fluktuasi. Penurunan NINV Manchester United yang signifikan pada periode 2019 disebabkan oleh kegagalan klub dalam merekrut beberapa pemain yang diinginkan di bursa transfer. Alasannya tentu karena prestasi Manchester United yang semakin menurun dalam beberapa musim terakhir membuat menurunnya tingkat kepercayaan pemain sepak bola terhadap Manchester United. Namun, NINV Manchester United mengalami kenaikan pada periode 2020 karena restrukturisasi kepelatihan dan skuad utama sehingga klub mengeluarkan lebih banyak dana untuk merekrut pemain. Hasilnya cukup memuaskan karena klub berhasil merekrut pemain yang sedang dalam performa baik seperti Bruno Fernandes dan Harry Maguire. Sementara itu, kenaikan dan penurunan NINV pada masing-masing periode 2019 dan 2020 dari rata-rata industri tidak terlalu signifikan karena banyaknya penjualan pemain selalu diiringi dengan investasi pembelian pemain sehingga $N I N V$ industri sejenis cenderung stabil.

Secara umum, dapat disimpulkan bahwa kinerjna keuangan menurut NINV Manchester United kurang baik daripada rata-rata industri. Fluktuasi rasio NINV Manchester United disebabkan karena begitu besarnya selisih pembelian dan penjualan pemain yang artinya bahwa Manchester United tidak dapat mengimbangi pembelian pemain dengan penjualannya karena penurunan prestasi klub. Sementara itu, rasio NINV rata-rata industri sejenis lebih kecil dan secara tren cenderung stabil. Hal ini menandakan bahwa rata-rata industri dapat mengimbangi pembelian dan penjualan pemain.

Leverage Ratio

Rasio ini digunakan untuk mengukur kemampuan klub terkait besarnya aset yang dapat membiayai utangnya. Leverage ratio membandingkan antara kewajiban perusahaan dengan total asetnya. Suatu klub dapat dikatakan mempunyai tingkat leverage ratio yang tinggi apabila jumlah asetnya lebih sedikit dibandingkan jumlah kewajibannya. 
Tabel 2

Perbandingan Leverage Ratio antara Manchester United Plc dan Rata-Rata Industri Selama Periode 2018-2020

\begin{tabular}{ccccc}
\hline \multirow{2}{*}{ Objek } & \multicolumn{4}{c}{ Tahun } \\
\cline { 2 - 5 } & $\mathbf{2 0 1 8}$ & $\mathbf{2 0 1 9}$ & $\mathbf{2 0 2 0}$ & $\overline{\mathbf{x}}$ \\
\hline Manchester United & $72,37 \%$ & $72,26 \%$ & $74,61 \%$ & $73,08 \%$ \\
Rata-rata industri & $60,31 \%$ & $59,26 \%$ & $62,72 \%$ & $60,77 \%$ \\
\hline
\end{tabular}

Sumber: Diolah dari laporan keuangan klub Liga Inggris (2021)

Dari Tabel 13 tersebut dapat dikatakan bahwa rata-rata leverage ratio Manchester United berada di atas rata-rata industrinya. Artinya, kondisi keuangan Manchester United lebih berisiko karena total aset yang dimiliki tidak dapat menutupi kewajiban perusahaan selama periode 2018-2020. Pada tahun 2018 leverage ratio Manchester United berada di atas rata-rata industri, yaitu sebesar $72,37 \%$. Selanjutnya, terjadi penurunan leverage ratio sebesar $0,11 \%$ menjadi $72,26 \%$ pada tahun 2019 namun tetap berada di atas rata-rata industri. Pada periode 2020, terdapat kenaikan leverage ratio Manchester United dari $72,26 \%$ menjadi $74,61 \%$ karena penurunan total aset khususnya bagian kas dan setara kas sebagai dampak pandemi Covid-19. Secara keseluruhan, leverage ratio Manchester United berada di atas rata-rata industri. Hal ini dapat menimbulkan risiko bagi kondisi keuangan klub. Namun, baik Manchester United maupun rata-rata industri memiliki leverage ratio yang cenderung stabil meski keduanya sempat mengalami sedikit peningkatan rasio di tahun 2020 sebagai dampak pandemi Covid-19.

Analisis rasio keuangan lainnya

\section{Current Ratio}

Salah satu rasio likuiditas yang menggambarkan kemampuan klub untuk memenuhi kewajiban jangka pendeknya menggunakan aset lancar klub. Rasio ini diperoleh dengan membandingkan antara aktiva lancar dan kewajiban lancar. Semakin tinggi current ratio maka semakin baik kinerja keuangan sebuah klub. Pada tahun 2018, current ratio Manchester United berada di atas rata-rata industri, yaitu sebesar 89,60\%. Kemudian, di periode 2019 sempat mengalami sedikit peningkatan sebesar 0,95\% dari tahun sebelumnya menjadi $90,55 \%$. Kenaikan current ratio pada periode ini disebabkan oleh penurunan current liabilities klub Manchester United karena pendapatan yang ditangguhkan sudah dapat direalisasi oleh klub. Namun, penurunan current ratio secara drastis terjadi di periode selanjutnya.

Tabel 3

Perbandingan Current Ratio antara Manchester United Plc dan Rata-Rata Industri Selama Periode 2018-2020

\begin{tabular}{ccccc}
\hline \multirow{2}{*}{ Objek } & \multicolumn{4}{c}{ Tahun } \\
\cline { 2 - 5 } & $\mathbf{2 0 1 8}$ & $\mathbf{2 0 1 9}$ & $\mathbf{2 0 2 0}$ & $\overline{\mathbf{x}}$ \\
\hline Manchester United & $89,60 \%$ & $90,55 \%$ & $56,44 \%$ & $78,86 \%$ \\
Rata-rata industri & $85,18 \%$ & $72,47 \%$ & $71,93 \%$ & $76,53 \%$ \\
\hline
\end{tabular}

Sumber: Diolah dari laporan keuangan klub Liga Inggris (2021)

Current ratio Manchester United mengalami penurunan yang signifikan dari $90,55 \%$ menjadi $56,44 \%$ pada periode 2020. Penurunan ini membuat current ratio Manchester United berada di bawah rata-rata industrinya yang sebesar 71,93\%. Hal tersebut disebabkan oleh turunnya akun kas dan setara kas diiringi dengan penurunan current asset klub secara signifikan sehingga memengaruhi pertumbuhan current ratio di 
periode 2020. Secara umum, dapat disimpulkan bahwa rata-rata current ratio Manchester United berada di atas rata-rata industri meskipun terjadi penurunan secara tren selama periode 2018-2020. Sementara itu, current ratio terburuk Manchester United terjadi pada periode 2020 karena pertumbuhan yang menurun signifikan sebesar 34,11\%. Hal ini lantas membuat klub berisiko pailit karena dikhawatirkan tidak mampu membayar kewajiban lancarnya sebagai dampak pandemi Covid-19.

Assets Turnover

Rasio aktivitas untuk mengukur kemampuan klub menghasilkan penjualan dari total asetnya dengan cara membandingkan penjualan bersih dengan total aset. Semakin tinggi rasio maka sebuah klub efisien mengelola asetnya untuk menghasilkan penjualan.

Tabel 4.

Perbandingan Assets Turnover antara Manchester United Plc dan Rata-Rata Industri Selama Periode 2018-2020

\begin{tabular}{ccccc}
\hline \multirow{2}{*}{ Objek } & \multicolumn{4}{c}{ Tahun } \\
\cline { 2 - 5 } & $\mathbf{2 0 1 8}$ & $\mathbf{2 0 1 9}$ & $\mathbf{2 0 2 0}$ & $\overline{\mathbf{x}}$ \\
\hline Manchester United & $38,15 \%$ & $41,91 \%$ & $36,79 \%$ & $38,95 \%$ \\
Rata-rata industri & $45,57 \%$ & $46,64 \%$ & $41,61 \%$ & $44,61 \%$ \\
\hline
\end{tabular}

Sumber: Diolah dari laporan keuangan klub Liga Inggris (2021)

Berdasarkan Tabel 13 diperoleh data assets turnover Manchester United di tahun 2018 sebesar 38,15\%. Angka ini berada di bawah rata-rata industri sebesar 45,57\%. Assets turnover Manchester United sempat mengalami kenaikan sebesar 3,76\% menjadi 41,91\% pada periode 2019 karena proporsi kontrak pemain Manchester United dalam aset perusahaan mengalami penurunan sehingga memengaruhi total aset. Kemudian, assets turnover Manchester United kembali turun menjadi 36,79\% pada periode 2020 saat masa pandemi Covid-19. Hal ini disebabkan oleh turunnya jumlah aset maupun penjualan klub namun penurunan penjualannya lebih besar daripada penurunan total assets.

Perputaran aset Manchester United cenderung bergerak fluktuatif selama periode 2018-2020 dan masih berada di bawah rata-rata industri. Selama rentang 2018-2020, ratarata assets turnover Manchester United adalah 38,95\%. Klub hanya menghasilkan 0,38 kali penjualan pada setiap 1 kali yang diinvestasikan dalam aset klub. Assets turnover yang cukup rendah ini menandakan kurang efisiennya manajemen dalam memanfaatkan aset klub untuk menghasilkan penjualan di masa pandemi Covid-19.

Return on Assets

Rasio ini adalah salah satu rasio profitabilitas yang digunakan untuk mengukur hasil dari investasi atas aset yang digunakan oleh klub dengan cara membagi laba bersih dengan total asetnya. Rasio ini dapat menunjukkan seberapa efisien perusahaan dalam mengelola aset untuk menghasilkan lama selama periode tertentu. Semakin tinggi rasio maka semakin baik perusahaan dalam mengelola asetnya untuk menghasilkan laba.

Tabel 5.

Perbandingan Return on Assets antara Manchester United Plc dan Rata-Rata Industri Selama Periode 2018-2020

\begin{tabular}{ccccc}
\hline \multirow{2}{*}{ Objek } & \multicolumn{4}{c}{ Tahun } \\
\cline { 2 - 5 } & 2018 & 2019 & 2020 & $\overline{\mathrm{x}}$ \\
\hline Manchester United & $-2,43 \%$ & $1,26 \%$ & $-1,68 \%$ & $-0,95 \%$ \\
Rata-rata industri & $6,06 \%$ & $-0,55 \%$ & $-3,87 \%$ & $0,54 \%$ \\
\hline
\end{tabular}

Sumber: Diolah dari laporan keuangan klub Liga Inggris (2021) 
Rata-rata return on assets Manchester United berada di bawah rata-rata industri yang sejenis selama periode 2018-2020. Rata-rata return on assets Manchester United bahkan mencapai angka $-0,95 \%$. Hal ini berarti perusahaan tidak cukup efektif dalam memanfaatkan asetnya untuk menghasilkan laba yang optimal. Namun, secara tren, return on assets Manchester United masih dapat dikatakan stabil dibandingkan rata-rata industri sejenisnya yang menurun signifikan selama periode 2018-2020. Secara tren, return on assets Manchester United masih cukup stabil meskipun sempat menyentuh angka negatif. Return on assets Manchester United sempat mengalami kenaikan dan menyentuh angka positif di tahun 2019, yaitu 1,26\%. Peningkatan terjadi karena Manchester United membayar pajak jauh lebih rendah sehingga laba bersih mengalami kenaikan yang lebih besar daripada kenaikan total aset. Namun akhirnya terdapat penurunan pada periode 2020 menjadi -1,68\% karena klub mengalami kerugian dari pelepasan aset tidak berwujud sehingga penjualan pemain tidak mampu menutupi kerugian operasinya.

Secara umum dapat disimpulkan bahwa return on assets Manchester United cenderung stabil meskipun secara rata-rata masih dibawah industri yang sejenis selama periode 2018-2020. Namun hal ini mengindikasikan bahwa Manchester United memiliki kemampuan yang cukup efektif dalam mengelola asetnya guna menghasilkan laba walaupun berada di masa sulit pandemi seperti saat ini.

Debt to Equity Ratio

Rasio ini adalah salah satu rasio solvabilitas untuk megukur seberapa baik struktur investasi perusahaan apabila dilihat dari proporsi kewajiban dan ekuitasnya. Rasio ini dapat dicari dengan cara membagi total kewajiban dengan ekuitas perusahaan. Semakin kecil nilai rasio ini maka semakin baik kinerja perusahaan dalam memenuhi kewajibannya dengan modal yang ada.

Tabel 6.

Perbandingan Debt to Equity Ratio antara Manchester United Plc dan Rata-Rata Industri Selama Periode 2018-2020

\begin{tabular}{ccccc}
\hline \multirow{2}{*}{ Objek } & \multicolumn{4}{c}{ Tahun } \\
\cline { 2 - 5 } & $\mathbf{2 0 1 8}$ & $\mathbf{2 0 1 9}$ & $\mathbf{2 0 2 0}$ & $\overline{\mathbf{x}}$ \\
\hline Manchester United & $261,91 \%$ & $260,43 \%$ & $293,89 \%$ & $272,08 \%$ \\
Rata-rata industri & $180,26 \%$ & $176,68 \%$ & $220,30 \%$ & $192,41 \%$ \\
\hline
\end{tabular}

Sumber: Diolah penulis (2021) (2021)

Debt to equity ratio Manchester United pada tahun 2018 turun sebesar 1,48\% dibandingkan periode sebelumnya menjadi 260,43\%. Namun di tahun 2020 terjadi peningkatan yang cukup tinggi sebesar 33,46\% dibandingkan periode 2019 menjadi $293,89 \%$. Peningkatan yang signifikan ini terjadi karena penurunan laba ditahan perusahaan akibat kerugian tahun 2020 serta pembayaran dividen yang cukup besar bagi investor sehingga memengaruhi total ekuitas perusahaan. Secara tren debt to equity ratio Manchester United cenderung meningkat dalam rentang 2018-2020. Hal ini berarti pemenuhan kewajiban perusahaan dalam mengandalkan ekuitas terus mengalami penurunan. Apabila dibandingkan dengan rata-rata industrinya, debt to equity ratio Manchester United selalu lebih besar sehingga dapat berdampak pada sulitnya mencari tambahan modal dengan pinjaman dari kreditur.

Meskipun demikian, bagi perusahaan besar seperti Manchester United Plc yang sudah go public di bursa saham, rata-rata debt to equity ratio yang mencapai $272,08 \%$ mungkin masih dapat diterima karena proporsi aktiva perusahaan berada di atas rata-rata 
industri sehingga perlu banyak ekuitas untuk membiayai investasi jangka panjang. Ditambah lagi dengan hadirnya pandemi Covid-19 tentu berdampak pada kerugian perusahaan sehingga memengaruhi rasio utang.

\section{KESIMPULAN}

\section{Kesimpulan}

Komponen yang berperan dalam keseimbangan kondisi keuangan Manchester United Plc selama periode 2018-2020, yaitu komponen pendapatan, beban, dan player's registration. Manchester United memperoleh pendapatan melalui tiga sektor, yaitu pendapatan komersial, hak siar, dan matchday. Sektor komersial adalah pendapatan dengan proporsi terbesar, menyentuh angka $54,82 \%$ pada tahun 2020 . Namun sayangnya secara keseluruhan pendapatan kotor klub cenderung mengalami penurunan yang besar terutama sektor penyiaran dan pertandingan (matchday) sebagai dampak pandemi Covid19. Sementara itu, total beban Manchester United mengalami penurunan sebesar 13,15\% dibandingkan periode 2019. Hal tersebut karena aktivitas bisnis klub yang berkurang akibat pandemi Covid-19.

Dalam laporan keuangan Manchester United, pemain sepak bola diklasifikasikan sebagai aset tidak berwujud pos player's registration. Karena pertimbangan sebuah klub untuk membeli pemain sepak bola adalah dari kemampuan bermain sepak bolanya. Selanjutnya, pengukuran nilai wajar pemain dinilai dari biaya akuisisi dan biaya lain yang terkait. Biaya perolehan tersebut akan disesuaikan melalui amortisasi setiap akhir periode. Saat masa kontrak pemain habis, maka akan dilakukan pelepasan atau perpanjangan kontrak pemain. Apabila kontrak pemain diperpanjang, biaya perpanjangan kontrak akan dikapitalisasi ke dalam biaya perolehan. Apabila kontrak tidak diperpanjang, akan dilakukan pelepasan pemain berdasarkan nilai wajar dikurangi biaya transaksi.

Analisis kinerja keuangan Manchester United selama periode 2018-2020 menghasilkan kecenderungan penurunan kinerja terutama saat terjadi pandemi Covid-19, terutama dalam hal profitabilitas dan aktivitas. Covid-19 menyebabkan kerugian secara signifikan pada kinerja keuangan klub pada periode 2020. Dampaknya terutama menyebabkan penurunan pendapatan penyiaran (broadcasting) dan penjualan tiket pertandingan (matchday) akibat penundaan kompetisi yang seharusnya dimulai pada pertengahan Maret 2020. Terlebih lagi, penerbitan regulasi yang ditetapkan oleh panitia liga mengakibatkan penutupan stadion sepak bola Old Trafford, Museum klub, dan Megastore produk pada awal 2020. Selain itu, Manchester United kurang efisien ketika melakukan investasi jangka panjang. Klub mengeluarkan banyak dana restrukturisasi kepelatihan untuk meningkatkan prestasi klub namun berhasil merekrut beberapa pemain potensial pada bursa transfer 2020. Ditambah lagi, kinerja keuangan Manchester United dinyatakan baik dalam hal pengelolaan beban gaji karyawan yang efisien dan peningkatan pendapatan yang berasal dari kontrak sponsor. Dari analisis rasio tersebut juga ditemukan bahwa kinerja keuangan Manchester United ditentukan oleh bagaimana sebuah klub memperlakukan pemain sepak bola dalam laporan keuangannya sehingga hal tersebut berpengaruh baik dalam pos aset, investasi, pendapatan, maupun beban.

\section{Saran}

Berdasarkan penelitian ini, maka beberapa perusahaan lain yang bergerak di industri sepak bola dapat mengambil sisi positif atas kinerja keuangan Manhaster United dalam pengelolaan kinerja keuangannya. Hal ini juga perlu dicermati oleh beberapa klub sepak bola di Indonesia yang sudah berganti kepemilikan dari perserikatan menjadi 
sebuah perusahaan dan bahkan ada yang sudah go public ke Bursa Efek Indonesia. Kemudian terhadap penelitian selanjutnya adalah bisa dilakukan dengan melakukan penelitian dengan klub sepakbola berbeda di negara yang lain ataupun klub yang ada di Indonesia.

\section{REFERENSI}

Accounting for Football Club. (23 September 2008). StudyMode Research. https://www.studymode.com/essays/Accounting-For-Football-Club-165074.html

Amir, E., \& Livne, G. (2005). Accounting, Valuation and Duration of Football Player Contracts. Journal of Business Finance \& Accounting. 32(3): 41-70.

Club Licensing Regulation. (29 Oktober 2007). FIFA. www.FIFA.com

Fatih Ecer, A. B. (2014). Measuring Performances of Football Clubs Using Financial Ratios: The Gray Relational Analysis Approach. American Journal of Economics. 4(1): $62-71$.

Fraser, L., \& Ormiston, A. (2008). Memahami Laporan Keuangan. Jakarta: Indeks.

Hidayat, R. T. (2010). Analisis atas Laporan Keuangan Klub Sepak bola: Studi pada Klub Sepak bola Arsenal, Juventus, dan Barcelona. Tesis. Jakarta: Magister Akuntansi Fakultas Ekonomi Universitas Indonesia.

International Accounting Standard Board. (1998). International Accounting Standard No. 38 : Intangible Assets. London, UK.

Kasmir. (2013). Analisis Laporan Keuangan (edisi ke-1.). Depok: PT. Raja Grafindo Persada.

Kawistara, I. W. (27 Agustus 2020). Karakteristik Kualitatif Laporan Keuangan. KJA Ashadi dan Rekan. https://www.kjaashadirekan.co.id/5-karakteristik-kualitatiflaporan-keuangan-yang-perlu-anda-ketahui

Kinerja Keuangan. (27 Mei 2020). Dosen Pendidikan: https://www.dosenpendidikan.co.id/kinerja-keuangan/

Lisvery, S., \& Ginting, I. Y. (2004). Aktiva Tak Berwujud. Jurnal Akuntansi dan Keuangan Indonesia. 1: 1-15.

Pranata, E. C., \& Supatmi. (2014). Analisis Kinerja Keuangan pada Klub Sepak bola (Studi Kasus pada Arsenal, Tottenham Hotspur, dan Everton). Jurnal Ekonomi dan Bisnis. XVII(2): 41-70.

Rahman, H. A., \& Diyani, L. A. (2017). Kinerja Keuangan Klub-Klub Sepak Bola di Liga Inggris. Prosiding Seminar Nasional FPTVI. Panitia Seminar Nasional FPTVI 2017. Bali. 611-626.

Robinson, T. R., Munter, P., \& Grant, J. (2003). Financial Statement Analysis: A Global Approach. Prentice Hall.

Subramanyam, K. R. (2014). Analisis Laporan Keuangan. Jakarta: Salemba Empat.

Sujarweni, V. W. (2017). Analisis Laporan Keuangan. Yogyakarta: Pustaka Baru Press.

Wahyudiono, B. (2014). Mudah Membaca Laporan Keuangan. Jakarta: Raih Asa Sukses. 
Utama, A. (3 September 2020). Menyoal Brand Bernama 'Manchester United'. detikSport.https://sport.detik.com/aboutthegame/umpan-silang/d3260383/menyoal-brand-bernama-manchester-united

Zakky, M. (17 September 2018). Profil Manchester United |Fakta, Logo, Stadion dan Daftar Trofi Klub. Retrieved from JurnalisBola.com: https://www.jurnalisbola.com/profil-trofi-manchester-united/ 